\title{
Harmful Effects on Oryzaephilus surinamensis (L.) and Tribolium castaneum by Food Grade Antioxidants and their Formulations in Peanut Kernel
}

\author{
Daiana Garcia ${ }^{1 *}$, Natalia Soledad Girardi ${ }^{2}$, María Alejandra Passone ${ }^{1}$, Andrea Nesci ${ }^{1}$ and Miriam Etcheverry ${ }^{1}$ \\ ${ }^{1}$ Research Career, Consejo Nacional de Investigaciones Cientificas y Técnicas (CONICET), Argentina \\ ${ }^{2}$ Doctoral fellow of Consejo Nacional de Investigaciones Cientificas y Técnicas (CONICET), Argentina
}

\author{
Correspondence to: \\ Daiana Garcia \\ Research Career, Consejo Nacional de \\ Investigaciones Científicas y Técnicas \\ (CONICET), Argentina \\ Tel: +54 358-4676113 \\ Fax: +54 358-4676231 \\ E-mail:dgarcia@exa.unrc.edu.ar
}

Received: April 25, 2017

Accepted: June 27, 2017

Published: July 05, 2017

Citation: Garcia D, Girardi NS, Passone MA, Nesci A, Etcheverry M. 2017. Harmful Effects on Oryzaephilus surinamensis (L.) and Tribolium castaneum by Food Grade Antioxidants and their Formulations in Peanut Kernel. J Food Chem Nanotechnol 3(3): 86-92.

Copyright: (C) 2017 Garcia et al. This is an Open Access article distributed under the terms of the Creative Commons Attribution 4.0 International License (CC-BY) (http://creativecommons. org/licenses/by/4.0/) which permits commercial use, including reproduction, adaptation, and distribution of the article provided the original author and source are credited.

Published by United Scientific Group

\section{Abstract}

The aim of this study was to investigate effect of 2(3)-tert-butyl-4 hydroxyanisole (BHA) and 2,6-di(tert-butyl)-p-cresol (BHT) and their formulations on mortality, body weight and total protein content of Oryzaephilus surinamensis (L.) and Tribolium castaneum, Herbst; two natural pest of stored peanut. The effect of free BHA and BHT and their formulations (F-BHA and F-BHT) at dose range to 10 from $45 \mathrm{mM}$, in peanut kernel was evaluated. BHA and BHT free antioxidant showed significant mortality percentages upper than $80 \%$. Besides, microencapsulated antioxidants at 20 and $30 \mathrm{mM}$ significantly affected the survival of insect populations after 45 days of exposure. BHA and BHT formulation showed insecticidal activity of 100 and 70\%, respectively. Insect weight was significantly affected by all studied treatments and the major effect for O. surinamensis was produced by time especially with the application of BHA follow by F-BHA and F-BHT. Body mass weight of T. castaneum showed the highest reduction after application of F-BHA, followed F-BHT, BHT and BHA. Total protein content of insects also was affected by both free antioxidants and formulation treatments. Formulations preserved insecticidal effectiveness of antioxidants and extended their effect for up to 45 days which could act as new strategies to control these insect pests. Besides, sub-lethal levels of these compounds results in a loss of insects' weight and change in protein content. Results showed the first step in the toxicity of free and microencapsulated formulations of BHA and BHT against O. surinamensis and T. castaneum.

\section{Keywords}

BHA, BHT, Oryzaephilus surinamensis, Tribolium castaneum, Microcapsules

\section{Introduction}

Argentina is one of the major producer and supplier of food worldwide. Córdoba, from the center of this country, is an important peanut producing area. In 2015/16 harvest season Argentina had a total production around of 1.17 million tons ranking seventh among the world's largest producers of peanut [1]. Primary peanut production is intended for both industrialization and exportation and for the last case there is fluctuation between 0.44 and 0.68 million tons since 2012 [2]. Peanut, in their different presentations, is very little consumed internally which makes all production is oriented to exportation. At the moment industry elaborate peanut for direct consume and flavored peanut, pasta and peanut butter, oil and peanut pellets. Considering that $6 \%$ of the raw material can be lost due to fungi contamination and infest with insect during harvest, transport and storage, so it is necessary to have safe methods of preservations and control to the different contaminants. 
Two important species of insect pest saw-toothed grain beetle [Oryzaephilus surinamensis (L.) (Coleoptera; Silvanidae)] and the red flour beetle [Tribolium castaneum Herbst (Coleoptera; Tenebrionidae)] which attack already infested or malformed grains, preferring stored cereal products and oleaginous seeds [3-5]. Besides, they can acts as vector for potential toxigenic molds such as Aspergillus spp. and the constant migration of insect populations within granary ecosystem efficiently contributes to dispersion of viable fungal spores which are carried on the vector's body surface or are deposited with its feces [6]. Some research has shown that both type of genera of these insects' acts as vector of Aspergillus flavus in storage seeds as maize and peanut [7-9]. Control of these types of insects is considered of great importance as they can remain in continuous contact with raw material in the storage system, thus they can disperser fungal spores of fungi potentially producing mycotoxins.

Some works have demonstrated butylated hydroxyanisole (BHA) and butylated hydroxytoluene (BHT) (phenolic antioxidants) effectiveness against toxigenic molds and these storage pests $[10,11]$. However, analysis of antioxidant residual levels in stored peanuts showed a fast reduction of these substances, probably due to the environmental and biological factor interactions [12]. To improve the performance of these preservatives "in situ" both antioxidants were subjected to a microencapsulation process in order to protect them of different environmental agents according to Girardi et al. [13], who reported residual levels after 2 and 3 of storage months. Previous studies showed that both formulations maintained the insecticidal effect against O. surinamensis for more than 45 days [9]. Insecticidal activity of pure BHA and formulation of both antioxidants were demonstrated in O. surinamensis by Nesci et al. [7] and Garcia et al. [9], respectively. However, insecticidal activity on $T$. castaneum and harmful effects on both types of insects it is unknown. To advance in this sense, the proposal of this study was to investigate effect of free and microencapsulated $\mathrm{BHA}$ and BHT on i) mortality; ii) body weight and iii) total protein content in O. surinamensis and $T$. castaneum.

\section{Materials and Methods}

\section{Substrate and insects}

Natural peanuts collected during the harvest season 20142015 from Córdoba, Argentina, with an initial water content of 0.67 were used throughout this study. Seeds were sterilized by autoclave at $120{ }^{\circ} \mathrm{C}$ for $20 \mathrm{~min}$ and water activity $\left(\mathrm{a}_{\mathrm{w}}\right)$ was checked with an AquaLab Water Activity Meter 4TE (Decagon Devices, Inc.) with an accuracy of \pm 0.001 . Strain of the saw-toothed grain beetle $O$. surinamensis and red flour beetle $T$. castaneum were obtained from the Laboratory of Agricultural Zoology, Faculty of Agronomy, and University of Buenos Aires, Argentina. Mixed-sex adults 1-3 weeks old were used in the assays separately. Insects were reared on a diet of wheat flour, corn starch and yeast $(10: 10: 1.5)$ in plastic containers containing $200 \mathrm{~g}$ of the mixture at $27 \pm 1^{\circ} \mathrm{C}$ and 70 $\pm 5 \%$ relative humidity $(\mathrm{RH})$.

\section{Preparation of antioxidant formulation}

Industrial grade antioxidants, 2(3)-tert-butyl-4 hydroxyanisole (BHA) and 2,6-di(tert-butyl)-p-cresol (BHT), obtained from Eastman Chemical Company (Kingsport, Tennessee, USA) were used as core material. BHA had a purity of $98.5 \%$ containing as trace elements sulphated ash $100 \mu \mathrm{g} / \mathrm{g}$, citric acid $2.5 \mu \mathrm{g} / \mathrm{g}$, arsenic $3 \mu \mathrm{g} / \mathrm{g}$, and heavy metals $10 \mu \mathrm{g} / \mathrm{g}$. BHT had a purity of $99 \%$ containing as contaminants ash 100 $\mu \mathrm{g} / \mathrm{g}$, arsenic $3 \mu \mathrm{g} / \mathrm{g}$ and heavy metals $10 \mu \mathrm{g} / \mathrm{g}$. Contaminant compounds of industrial grade antioxidants did not exceed allowed levels by JECFA [14]. Gelatin (type A, gel strength 240 bloom) and gum arabic were used as the wall material. All other chemicals used in this work were of analytical grade. Microcapsules were made by complex coacervation following the methodology proposed by Girardi et al. [13]. Microcapsules obtained were frozen at $-80^{\circ} \mathrm{C}$ during 3 hours and freeze-dried with a chamber (L-T8-A-B3-CT, RIFICOR) pressure $<0.05$ mbar and $-45{ }^{\circ} \mathrm{C}$ for $72 \mathrm{~h}$. Empty capsules were performed with the same methodology but without the addition of BHA or BHT, in order to be used as control by replacing the core material with peanut oil.

\section{Microcosm assay}

Insecticidal effect determination: To determine insecticidal activity of free chemicals and in their formulations, $150 \mathrm{~g}$ of sterile peanut kernels were distributed into plastic jars of $500 \mathrm{~mL}$ capacity and treatments were added at different doses: 10, 20 and $30 \mathrm{mM}$ for O. surinamensis and 15, 30, 45 $\mathrm{mM}$ for T. castaneum. Fifteen adults of each type of insect were introduced into a jar and incubate in chamber under controlled conditions $\left(25 \pm 1{ }^{\circ} \mathrm{C}, 70 \pm 5 \%\right.$ r.h. $)$. Assay was done using three replicates per treatment and number of dead insect was determined at different times during a 45 days holding period. Treatments with empty capsules (without BHA or BHT) and without capsules were used as control.

Body weight evaluation: Insects were weight before to start the assay (time 0 ) and at different period time till the end of the experiment for all conditions (treatment and controls). Weight loss was calculated by difference between the data obtained at the different evaluation times.

\section{Protein content evaluation}

Protein content extraction: To determine protein content of insects affected by the presence of free and microencapsulated antioxidants, $100 \mathrm{~g}$ of sterile peanut kernels were distributed into plastic jars of $300 \mathrm{~mL}$ capacity with 15 adults of each insect species. Antioxidants pure and their formulations were added at non-lethal doses: 3 and $1 \mathrm{mM}$ of BHA and BHT respectively, for O. surinamensis while for T. castaneum 25 and $3 \mathrm{mM}$ for BHA and BHT respectively, were used. Jars were incubated in chamber under controlled conditions $\left(25 \pm 1{ }^{\circ} \mathrm{C}\right.$, $70 \pm 5 \%$ r.h.). Total proteins were extracted by Lee et al. [15] method with some modifications: insects exposed to chemical treatments and controls were homogenized with a pestle and mortar in $1 \mathrm{~mL}$ of $10 \mathrm{mM}$ Tris- $\mathrm{HCl}$ buffer, $\mathrm{pH} 7.5$, containing $0.5 \%(\mathrm{w} / \mathrm{v})$ Triton $\mathrm{X}-100$. The resultant homogenates were centrifuged at $5000 \mathrm{rpm}$ for $20 \mathrm{~min}$ using a Presvac (INS- 
EPF-12-A) centrifuge to remove exoskeletal and tissue debris. Supernatants were used as crude protein extracts.

Protein content detection and quantification: To detect and quantify protein level, Biuret reaction was used: $100 \mu \mathrm{L}$ of crude protein extract was mixed with $1 \mathrm{~mL}$ of Biuret reagent. After 5 minutes, absorbance at $545 \mathrm{~nm}$ was measured with a spectrophotometer (Spectrum SP 2100UV) using Biuret solution mixed with and Tris-HCl buffer as blank. A standard curve was calculated using bovine serum albumin (BSA) in a concentration range from 1 to $200 \mathrm{mg} / \mathrm{mL}$. The assay was done using three replicates per treatment at different times from 0 to 18 days holding period. Treatments with empty capsules (without BHA or BHT) and without capsules were used as controls.

\section{Data analyzed}

The effect of treatment on mortality, body weight and protein content was analyzed with ANOVA. Fisher's least significant difference (LSD) tests were performed to establish differences among mean values of variables at $p<0.05$. Probit analysis [16] was performed to estimate lethal time $50\left(\mathrm{LT}_{50}\right)$ and lethal doses $50\left(\mathrm{LD}_{50}\right)$ with a confidence limit of $95 \%$. Statistical analyses were carried out with Statgraphics ${ }^{\circledR}$ Centurion version XVI.I (Manugistics, Inc, Maryland, USA).

\section{Results}

Insecticidal activity of free and microencapsulated BHA and BHT Insecticidal

Toxicity of free antioxidants (BHA and BHT) and their formulations (F-BHA and F-BHT) against O. surinamensis is summarized in Figure 1A. Mortality percentages of this insect estimated in peanut samples treated with both 1) without capsules (CWC) and 2) empty capsules (CEC) controls were 35 and 55\%, respectively. Free BHA showed significant mortality percentages $(p<0.05)$ upper than $80 \%$ for all studied doses, while free BHT was able to dead the $100 \%$ of insects at all antioxidant concentrations assayed. Besides, $30 \mathrm{mM}$ of both microencapsulated chemical compounds affected significantly the survival of $O$. surinamensis population after 45 days of exposure $(\mathrm{F}-\mathrm{BHA}=100 \%$ and $\mathrm{F}-\mathrm{BHT}=70 \%)$.

Lethal time $50\left(\mathrm{LT}_{50}\right)$, is the needed time to kill $50 \%$ of tested population. Registered values of this parameter under the effect of 20 and $30 \mathrm{mM}$ of free BHA were 13 and 4 days, respectively (Table 1). While for F-BHA and for the same doses, values were 3 and 2 times lower than free antioxidant (4 and 2.6 days). However, $\mathrm{LT}_{50}$ obtained with free BHT was around 6 days for the three studied doses; but under the effect of the formulation, time was extended up to 23 and 22 days for 20 and $30 \mathrm{mM}$, respectively. Besides, lethal concentration 50 (LC50) was evaluated at 45 days of assay. This parameter showed the needed doses of a compound to kill $50 \%$ of tested population. For this type of insect, BHT showed the lowest value $(3 \mathrm{mM})$ follow by BHA $(5 \mathrm{mM})$. However, when antioxidants were encapsulated $\mathrm{LC}_{50}$ values increased 2 and 6 times for F-BHA and F-BHT, respectively.
On the other hand, total population of $T$. castaneum survived along 45 days of holding period in CWC samples. Only CEC revealed a $30 \%$ of mortality (Figure 1B). Besides, these insects showed around $35-60 \%$ of mortality in presence of free BHA being $45 \mathrm{mM}$ the best doses to kill them (Figure 1B). However, BHT pure compound showed the best insecticidal activity with mortality higher than $90 \%$ regardless of the dose assayed $(15,30$ and $45 \mathrm{mM})$. A reduction of the insecticidal activity was observed with the application of microencapsulated antioxidant. Thus, F-BHA did not exceed $40 \%$ of dead insects and mortality percentages registered after F-BHT application were 10, 50 and $100 \%$ for 15, 30 and 45 $\mathrm{mM}$, respectively.

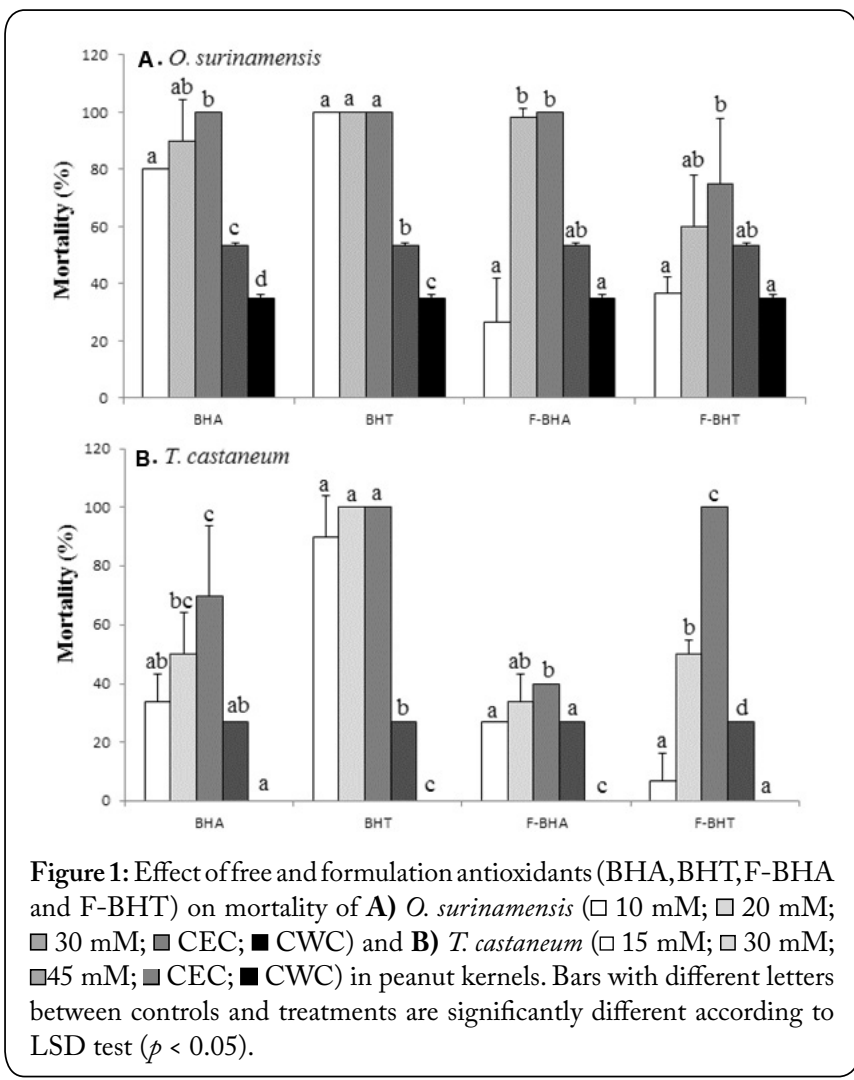

Lethal time 50 values for T. castaneum are shown in Table 1 and values were between 38 and 64 days for the three levels assayed for free BHA. However, for the BHA formulation values were $40 \%$ higher than free compound. On the other hand, values of $\mathrm{LT}_{50}$ recorded for BHT were around 15 days.

Table 1: Lethal time $50\left(\mathrm{LT}_{50}\right)$ values of $O$. surinamensis and T. castaneum affected by the application free BHA (BHA), free BHT (BHT), microencapsulated BHA (F-BHA) and microencapsulated BHT (F-BHT).

\begin{tabular}{|l|l|l|l|l|l|l|}
\hline \multicolumn{7}{|c|}{ Lethal time 50 (days) } \\
\hline & $\mathbf{1 0} \mathbf{~ m M}$ & $\mathbf{2 0} \mathbf{~ m M}$ & $\mathbf{3 0} \mathbf{~ m M}$ & $\mathbf{1 5} \mathbf{~ m M}$ & $\mathbf{3 0} \mathbf{~ m M}$ & $\mathbf{4 5} \mathbf{~ m M}$ \\
\hline BHA & 15 & 13 & 4 & 64 & 50 & 38 \\
\hline BHT & 5 & 6 & 7 & 19 & 15 & 12 \\
\hline F-BHA & 47 & 4 & 2.6 & 89 & 60 & 104 \\
\hline F-BHT & 51 & 23 & 22 & 97 & 41 & 10 \\
\hline
\end{tabular}


The lowest value of this parameter for F-BHT was observed at $45 \mathrm{mM}$ (10 days). When $\mathrm{LC}_{50}$ was evaluated, BHT and the formulation showed the lowest values for this insect (11 and 29 days, respectively). While, a double dose of F-BHA (65 $\mathrm{mM}$ ) was required to achieve the same effect as the free BHA $(29 \mathrm{mM})$.

Insects body weight variation affected by the application of free and microencapsulated BHA and BHT

Effects of single factors (treatment-T and time-t) as well as their two way interactions on insect body weight for $O$. surinamensis treated with free antioxidants and their formulations, including both types of controls, were determined by ANOVA test $(p<0.05)$ (Table 2). Insect weight was significantly affected by all studied treatment (except by free BHT), $t$ and their interactions. The major effect was produced by $t$, especially with the application of BHA followed by F-BHA and F-BHT. Effect of free antioxidants and formulations on body weight of this insect species through time is summarized in Figure 2A. Significant differences were found for treatment in each evaluated time $(0,5,11,15$ and 18 days) on body weight compared with both controls according to LSD test $(p<0.05)$. In general, weight of insect decreased in all treatment and control (except for CEC) in the order of 62 , 38, 64, 69 and 23\% for BHA, F-BHA, BHT, F-BHT, CWC, respectively from time 0 to 5 days. While for CEC, an increase in body weight around a $26 \%$ was observed during the same period time (0 to 5 days). Significant reduction $(p<0.05)$ on body weight was found at the end of the experiment (18 days) compared with the initial time (0 days), especially for insects treated with BHA and F-BHA with a 38 and $69 \%$ of decrease, respectively. This type of insect treated with BHT and F-BHT showed a body weight 3 times lower than the initial weight after 5 days of treatment. However, this value was gradually increasing throughout time but only $O$. surinamensis treated with the free antioxidant recovered initial weight at the final of the assay.

Table 2: ANOVA test. Effect of treatment $(\mathrm{T})$ and time $(\mathrm{t})$ and their interactions on the $O$. surinamensis body weight in presence of free BHA (BHA), microencapsulated BHA (F-BHA), free BHT (BHT) and encapsulated BHT (F-BHT).

\begin{tabular}{|l|l|l|l|l|l|l|l|l|l|}
\hline Factors & DF & \multicolumn{2}{|c|}{ BHA } & \multicolumn{2}{c|}{ F-BHA } & \multicolumn{2}{c|}{ BHT } & \multicolumn{2}{c|}{ F-BHT } \\
\hline & & MS & $f$-value & MS & $f$-value & MS & $f$-value & MS & $f$-value \\
\hline T & 2 & 7.5 & $1197.4^{*}$ & 2.7 & $223.2^{*}$ & 0.2 & 1.4 & 2.2 & $112.2^{*}$ \\
\hline $\mathbf{t}$ & 4 & 10.1 & $1603.5^{*}$ & 11.6 & $965.2^{*}$ & 6.4 & $55.2^{*}$ & 7.1 & $355.5^{*}$ \\
\hline T"t & 8 & 6.4 & $1020.4^{*}$ & 6.5 & $539.6^{*}$ & 10.3 & $88.7^{*}$ & 8.5 & $424.9^{*}$ \\
\hline Error & 38 & 0 & & 0.0 & & & & 0 & \\
\hline
\end{tabular}

DF: degree freedom; MS: mean square. Values with asterisk are statistically significant $(p<0.05)$

Respect to T. castaneum, ANOVA test showed that body weight evaluation for this insect was significantly affected $(p$ $<0.05$ ) by all treatments and times assayed (except for time in presence of F-BHT) (Table 3). Figure 2B shows body weight of $T$. castaneum at the different times as affected by all studied treatments. Both controls (CEC and CWC), showed a

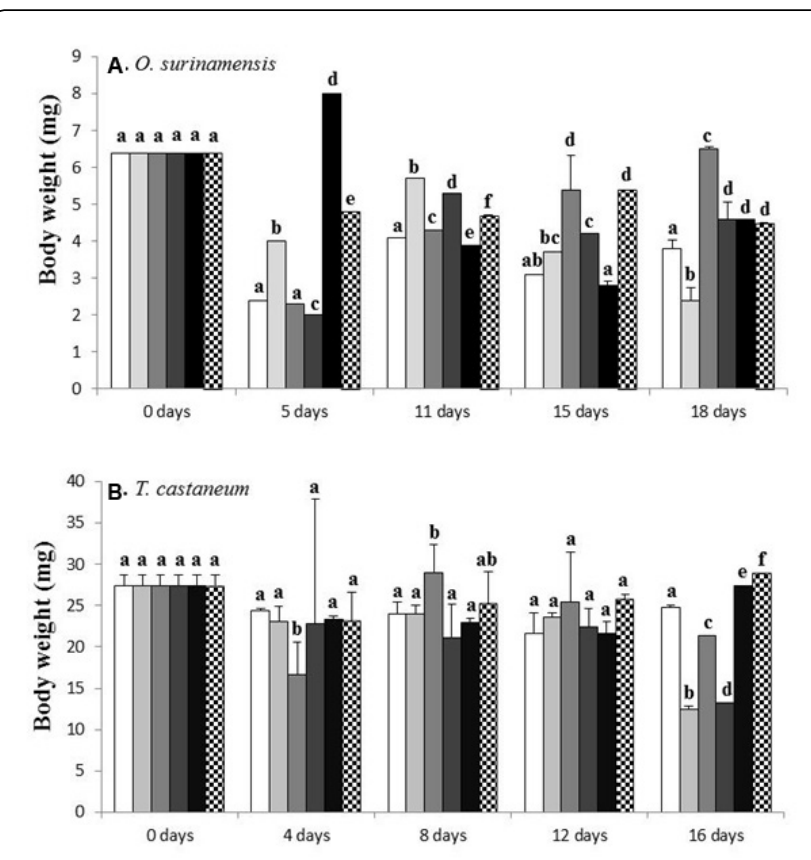

Figure 2: Changes in mean body weights of treated and control A) $O$. surinamensis and B) T. castaneum on peanut kernel. $\square$ BHA; $\square$ F-BHA;

BHT; $\square$ F-BHT; $\square$ CEC; and $\boldsymbol{\square}$ CWC. Data are presented as mean of three replicates \pm standard deviations. Bars with different letters for each time between controls and treatments are significantly different according to LSD test $(p<0.05)$.

reduction of $28 \%$ in insect weight after 4 days, but the weight was increasing with time reaching initial values at the end of the study (16 days).

In general, insects treated with free and encapsulated antioxidants showed that body weight was gradually decreased with time. Significant differences of this parameter were observed between treatments and controls according to LSD test $(p<0.05)$. The highest reduction of the weight was observed with the application of F-BHA (64\%), followed by F-BHT, BHT and BHA with 60, 28 and $11 \%$ of decreased, respectively, at the end of the assay (16 days) compared with initial time (0 days).

Table 3. ANOVA test. Effect of treatment $(T)$ and time $(t)$ and their interactions on the $T$. castaneum body weight in presence of free BHA (BHA), microencapsulated BHA (F-BHA), free BHT (BHT) and encapsulated BHT (F-BHT).

\begin{tabular}{|l|l|l|l|l|l|l|l|l|l|}
\hline Factors & DF & \multicolumn{2}{|c|}{ BHA } & \multicolumn{2}{c|}{ F-BHA } & \multicolumn{2}{c|}{ BHT } & \multicolumn{2}{c|}{ F-BHT } \\
\hline & & MS & $f$-value & MS & $f$-value & MS & $f$-value & MS & $f$-value \\
\hline $\mathbf{T}$ & 2 & 13.5 & $4.1^{*}$ & 69.4 & $23.0^{*}$ & 26.5 & $3.5^{*}$ & 99.2 & $4.4^{*}$ \\
\hline $\mathbf{t}$ & 4 & 39.5 & $11.9^{*}$ & 29.9 & $9.9^{*}$ & 60.3 & $7.9^{*}$ & 33.6 & 1.5 \\
\hline $\mathrm{T}^{*} \mathbf{t}$ & 8 & 6.9 & 2.1 & 53.5 & $17.7^{*}$ & 43.2 & $5.7^{*}$ & 43.2 & 1.93 \\
\hline Error & 38 & 3.3 & & 3.0 & & 7.6 & & 22.4 & \\
\hline
\end{tabular}

DF: degree freedom; MS: mean square. Values with asterisk are statistically significant $(p<0.05)$

Insects total protein content affected by the application of free and microencapsulated BHA and BHT

Figure $3 \mathrm{~A}$ shows total protein content of O. surinamensis 
affected by the application of free and encapsulated antioxidants as a function of time. Protein level detected in both controls (CWC and CEC) gradually increased throughout experimental time reaching 25 and $22 \mathrm{mg}$ protein/mg insect, respectively. These values are 5 times higher than initial concentrations.

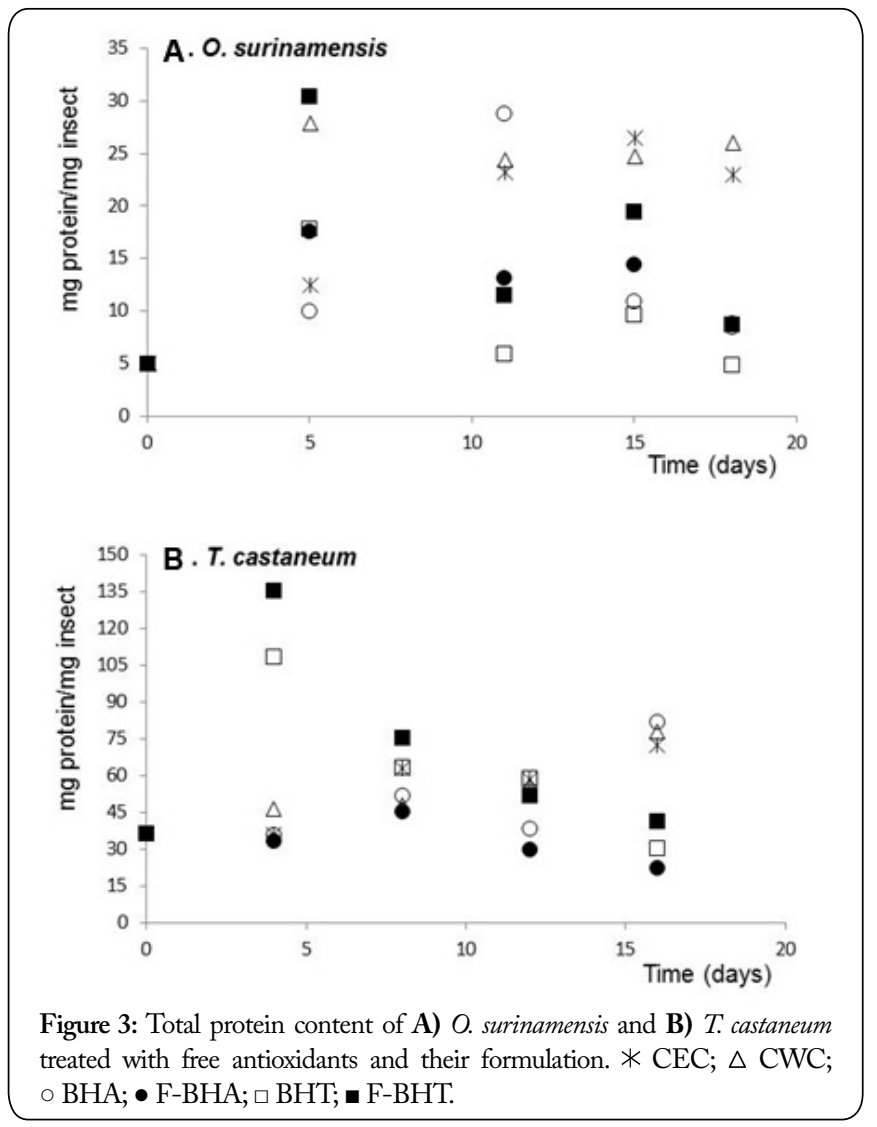

All treatments (BHA, F-BHA, BHT and F-BHT) applied to this insect revealed a peak in protein level around 11 days. However, after this time, the amounts start to decrease reaching levels 3 times lower than both controls at the end of the experiment.

As for O. surinamensis, protein content of T. castaneum showed a gradual increase when insects developed on both CWC and CEC samples range to 36 to 78 and $72 \mathrm{mg}$ protein $/ \mathrm{mg}$ insect, respectively at the end of the assay. Similar trend was observed when this pest was exposed to BHA, reaching 82 $\mathrm{mg}$ protein $/ \mathrm{mg}$ insect. However, insects showed a decreased of $39 \%$ in presence of F-BHA. Finally, both BHT and F-BHT produced an increment in protein levels during the first 5 days around of 3 and 4 times, respectively. Nevertheless, these levels were gradually reduced from 5 to 16 day, with final amounts of $30 \mathrm{mg}$, similar to the initial one.

\section{Discussion}

O. surinamensis and $T$. castaneum are two very important pests of stored grains producing economic losses. In this work the effect of the food grade antioxidants BHA and BHT, free and microencapsulated were evaluated on mortality, body weight and total protein content variations for these insects.
Particularly, for O. surinamensis both free antioxidants showed a high insecticidal activity (higher than $80 \%$ of mortality) after 45 days of incubation. Only BHA preserved the insecticidal effect in their formulation for the two highest doses assayed (20 and $30 \mathrm{mM}$ ). Although, F-BHA doubled $\mathrm{LC}_{50}$ value respect to free $\mathrm{BHA}, \mathrm{LT}_{50}$ value was reduced around 3 and 2 times at 20 and $30 \mathrm{mM}$, respectively. However, when F-BHT was evaluated, both $\mathrm{LC}_{50}$ and $\mathrm{LT}_{50}$ were more than 3 times higher compared with the free antioxidant. *Notably that result of mortality, $\mathrm{LD}_{50}$ and $\mathrm{LT}_{50}$ from this insect by F-BHA and F-BHT were extracted from Garcia et al. [9]. In the case of T. castaneum, mortality never exceed the 70\% of dead insects with the application of pure BHA, and with application of formulation the maximum observed mortality was $35 \%$ for the highest dose assayed $(30 \mathrm{mM})$. For this, $\mathrm{LT}_{50}$ values for $\mathrm{F}$-BHA were always higher than 45 days and $\mathrm{LC}_{50}$ value was twice higher compared with the free compound. Nevertheless, the total mortality of this insect was produced by the presence of the two highest doses of BHT ( 30 and 45 $\mathrm{mM})$. This effect was keeping for the highest dose assayed of F-BHT $(45 \mathrm{mM})$ where a decreased of 2 days for LT50 was recorded compared to the free chemical. Insecticidal effects of this food grade antioxidants without microencapsulation process (BHA and BHT) and the mixture of them (BHA/ BHT) were demonstrated against $O$. surinamensis in stored peanuts by Nesci et al. [7] with a $100 \%$ of mortality at $20 \mathrm{mM}$ of each chemical compound and the mixture $20 \mathrm{mM} / 20 \mathrm{mM}$. Also, Barra et al. [8] founded that free BHA and BHT and the mixture of them ( $20 \mathrm{mM}$ concentration) produced a high mortality against Sitophilus zeamais, Tribolium confusum and Rhyzopertha dominica after 120 days of incubation. Shtykova et al. [11] could to establish a complete inhibition of feeding on pine weevil (Hylobious abietis) with BHT microcapsules containing Eudragit copolymer and surfactant. However, in our work, a dual effect was observed of microencapsulated antioxidants; on the one hand F-BHA and F-BHT had the best insecticidal effect by reducing the $\mathrm{LT}_{50}$ value in $O$. surinamensis and T. castaneum respectively; but on the other hand the $\mathrm{LD}_{50}$ was more than double but always without exceeding the limits allowed of these antioxidants in peanut (200 $\mu \mathrm{g} / \mathrm{g}$ of peanut oil). This means that formulation made under complex coacervation preserved insecticidal effect of the antioxidants. As our knowledge, this is the first work that evaluates the influence of these food grade antioxidants (free and microencapsulated) against $O$. surinamensis and $T$. castaneum. Some works reported $\mathrm{LT}_{50}$ and $\mathrm{LD}_{50}$ values of this insect but they always used free compounds as commercial insecticides and essential oils [17-24].

Control methods of insects are based on the use of insecticides, which are generally the most effective management tools and provide the only feasible method of reducing insect pest population to acceptable levels $[25,26]$. However, is important to know the effect of the insecticidal agents on the pests to avoid possible development of resistance and evaluate the implementation of the product in the ecosystem. In this sense, we evaluated changes in body weight and total protein content of both insect pests in presence of sublethal levels $(3$ and $1 \mathrm{mM}$ for $O$. surinamensis and 2.5 and $3 \mathrm{mM}$ 
for T. castaneum for BHA and BHT, respectively) of free and microencapsulated antioxidants. Both controls (CWC and CEC), showed a maintenance of $O$. surinamensis body weight over time. However, from initial to the end of the experiment, addition of BHA showed around 38\% reduction of body weight and this decline was almost duplicated with the application of F-BHA. This effect may be is due to microcapsule wall material which could enhance the free antioxidant effect respect to the body weight reduction. In relation to $\mathrm{BHT}$ and its formulation, the influence on body weight was negligible $(3-5 \%)$ for this insect. On the other hand, a high decrease in body weight for T. castaneum was detected with the application of both antioxidant formulations with reductions of 52 and $46 \%$ for F-BHA and F-BHT respectively, being 6 to 11 times higher than free chemicals. As for $O$. surinamensis affected by BHA, microcapsule ingredients could help to the decreased T. castaneum body weight, giving specific properties of the capsules coating. This result is agreed with Shtykova et al. [11] and Garcia et al. [9] which founded an increase of insecticidal effect when these antioxidants were microencapsulated and evaluated against pine weevil (H. abietis) and O. surinamensis, respectively. Besides, Patil and Jadhav [27] founded change in mean body weight on the larval of Helicoverpa armigera when they fed leaves treated with $2000 \mathrm{Um} / \mathrm{L}$ of chitinase, where until day 7 insects showed a retarded in body mass. In our case, reduction of the weight in both insect could be due to an inhibition of feeding after 5-7 days. Many studies reported a high anti-feedant activity in insects using extracts of leaves and stems, essential oils, antioxidants, commercial insecticides and chemical compounds [28-34]. Particularly, Shtykova et al. [11], could establish an anti-feedant activity close to 1 (complete inhibition of feeding) on pine we evil with BHT microcapsules containing Eudragit copolymer and surfactant.

Finally, total protein content on both insects was altered by the presence of the antioxidants and their formulations, except with the interaction between free BHA and $T$. castaneum where final protein levels were similar to controls. This result is agreed with the mortality and body weight obtained with BHA application on this insect, which had no any effect. However, Khater and El-Shafiey [35] founded an increase in total protein content of $T$. castaneum by using $\mathrm{LC}_{50}$ of Wedelia trilobata (Fam.: Astracae) and Melissa officinalis (Fam.: Lamiacae) essential oils, suggesting that activity of protein biosynthesis attributed to synthesis of proteinases needed for insecticides substance detoxification [36]. In this study we show the decrease in proteins would be responsible for the weight loss observed after treatments. According to the existing information in this subject, this is the first research on the protein level detected in O. surinamensis by the presence of food grade insecticidal substance.

Results obtained of weight loss and variation in total protein content, using sub-lethal doses of free and microencapsulated antioxidants for both insect pests, may be attributed to a starvation effect, where insects lost weight and therefore, protein could acts as a source of energy thus decreasing their level. However, many authors revealed insects protein levels modifications after a starvation period and results are varied: e.g. Heller and Moklowska [37] reported a $40 \%$ decrease in the protein of Deilephila euphorbiae but no significant change in protein amounts were reported by Chaudahary et al. [38] in the larval composition of T. confusum. Hence, protein modifications evaluated under starvation effect is insect species dependent.

\section{Conclusion}

As conclusion, both food grade antioxidants and their formulations could acts as effective insecticidal agents against the studied insects especially BHA, BHT and F-BHA for O. surinamensis and $\mathrm{BHT}$ and $\mathrm{F}-\mathrm{BHT}$ for T. castaneum. In general, microcapsules solution process preserved insecticidal activity of antioxidants studied and extended their effect for up to 45 days. Therefore, microencapsulated antioxidants maintain their effect as in their free condition and could use as new strategies to control these pests. Besides, sublethal doses of these compounds resulted in a loss of insects' weight and change in protein content. Our results show the first step in the studied of mechanism of insect toxicity produced by free BHA and BHT and their formulations. It is of great importance because these organisms can develop some mechanism of resistance that can be transferred from generation to generation. Knowing the way in which these compounds acts, different ways of application of the formulation on the beans can be evaluated and modified their preparation in front of potential resistance. For this, further studies are needed to elucidate if an anti-feedant effect may be associated to the application of theses antioxidants and if there is a development of resistance to these insecticidal compounds by $O$. surinamensis and T. castaneum.

\section{Acknowledgment}

Authors acknowledge UNRC/CONICET for support under their programs. This work was carried out by grants from Agencia Nacional de Promoción Científica y Tecnológica (ANPCYT), FONCYT-PICT 1507/14 y PICT 1654/15.

\section{References}

1. USDA. 2015. Foreign agricultural service: Oilseeds and Products Update, yield and production, pp 4.

2. SIIA. 2015. Sistema Integrado de Información Agropecuaria. Informe cosecha 2015. Estimaciones agrícolas.

3. Howe RW. 1965. A summary of estimates of optimal and minimal conditions for population increase of some stored products insects. J Stored Prod Res 1(2): 177-184. https://doi.org/10.1016/0022474X(65)90018-4

4. Silva GAR, Lapenta AS. 2011. Genetic variability in esterases and the insecticide resistance in brazilian strains of Oryzaephilus mercator and Oryzaephilus surinamensis (Coleoptera: Silvanidae). Bull Entom Res 101(2): 177-185. https://doi.org/1017/S0007485310000325

5. Tucker AM, Campbell JF, Arthur FH, Zhu KY. 2014. Horizontal transfer of methoprene by Tribolium castaneum (Herbst) and Tribolium confusum Jacquelin du Val. J Stored Prod Res 57: 73-79. https://doi. org/10.1016/j.jspr.2013.12.001

6. Saint Geroges-Gridelet D. 1984. Effects of dietary lipids on the population growth of Dermatophagoides pteronyssinus. In: Proceedings of $6^{\text {th }}$ international congress of acarology, Chichester 1: 351-357.

7. Nesci A, Montemarani A, Passone MA, Etcheverry M. 2011. 
Insecticidal activity of synthetic antioxidants, natural phytochemicals, and essential oils against an Aspergillus section Flavi vector (Oryzaephilus surinamensis L.) in microcosm. J Pest Sci 84(1): 107-115. https://doi. org/10.1007/s10340-010-0333-2

8. Barra P, Nesci A, Etcheverry M. 2013. In vitro compatibility of natural and food grade fungicide and insecticide substances with Purpureocillium lilacinum and their effect against Aspergillus flavus.J Stored Prod Res 54: 67-73. https://doi.org/10.1016/j.jspr.2013.06.002

9. Garcia D, Girardi N, Passone MA, Nesci A, Etcheverry M. 2016. Evaluation of food grade antioxidant formulation for sustained antifungal, antiaflatoxigenic and insecticidal activities on peanut conditioned at different water activities. J Stored Prod Res 65: 6-12. https://doi.org/10.1016/j.jspr.2015.11.002

10. Nesci A, Barra P, Etcheverry M. 2011. Integrated management of insect vectors of Aspergillusflavus in stored maize, using synthetic antioxidants and natural phytochemicals. J Stored Prod Res 47(3): 231-237. https:// doi.org/10.1016/j.jspr.2011.03.003

11. Shtykova L, Masuda M, Sjodin EK, Marling E, Schlyter F, et al. 2008 Latex coatings containing antifeedants: formulation, characterization, and application for protection of conifer seedlings against pine weevil feeding. Progress in Organic Coatings 63(2): 160-166. https://doi. org/10.1016/j.porgcoat.2008.05.006

12. Passone MA, Funes GJ, Resnik SL, Etcheverry MG. 2008. Residue levels of food-grade antioxidants in postharvest treated in-pod peanuts during five months of storage. Food Chem 106(2): 691-697. https://doi org/10.1016/j.foodchem.2007.06.032

13. Girardi N, Garcia D, Nesci A, Passone MA, Etcheverry M. 2015. Stability of food grade antioxidants formulation to use as preservatives on stored peanut. LWT - Food Science and Technology 62(2): 1019-1026. https://doi.org/10.1016/j.lwt.2015.01.052

14. JECFA. 1996. Toxicological evaluation of certain food additives and contaminants in food. WHO Food Additives Series, No 35. Joint FAO/ WHO Expert committee on food additives, Geneva, Switzerland, pp 3-86.

15. Lee S-E, Lees EM, Campbell BC. 2000. Purification and characterization of an esterase conferring resistance to fenitrothion in Oryzaephilus surinamensis (L.) (insecta, coleoptera, silvanidae). J Agric Food Chem 48(10): 4991-4996. https://doi.org/10.1021/jf991258f

16. Finney DJ. 1971. Probit Analysis. Cambridge University Press.

17. Aggarwal N, Kumar R, Srivastva C, Dureja P, Khurana JM. 2010. Synthesis of nalidixic acid based hydrazones as novel pesticides.J Agric Food Chem 58(5): 3056-3061. https://doi.org/10.1021/jf904144e

18. de Melo BA, de Assis Cardoso Almeida F, Ferreira da Silva J, Maceió da Silva R. 2015. Insecticidal activity of Copaifera langsdorffi desf. (copaiba) oil against Tribolium castaneum (Coleoptera: Tenebrionidae) Revista Cubana de Plantas Medicinales 20(4): 419-428.

19. Ebadollahi A, Safaralizadeh M, Pourmirza A. 2010. Fumigant toxicity of Lavandula stoechas L. oil against three insect pests attacking stored products. J Plant Prot Res 50(1): 56-60. https://doi.org/10.2478/ v10045-010-0010-8

20. Guo SS, You C-X, Liang J-Y, Zhan, W-J, Gen Z-F, et al. 2015. Chemical composition and bioactivities of the essential oil from Etlingera yunnanensis against two stored product insects. Molecules 20: 15735-15747. https://doi.org/10.3390/molecules200915735

21. Negahban M, Moharramipour S, Sefidkon F. 2006. Insecticidal activity and chemical composition of Artemisia sieben besser essential oil from Karaj, Iran. J Asia Pac Entomol 9(1): 61-66. https://doi.org/10.1016/ S1226-8615(08)60276-9

22. Pourmirza AA. 2006. Effect of acrolein vapors on stored-product insects and wheat seed viability. J Econ Entomol 99(5): 1920-1924. https://doi. org/10.1093/jee/99.5.1920
23. Pourmirza AA, Tajbakhsh M. 2008. Studies on the toxicity of acetone, acrolein and carbon dioxide on stored-product insects and wheat seed. Pak J Biol Sci 11(7): 953-963. https://doi.org/10.3923/ pjbs.2008.953.963

24. Toews MD, Subramanyam B. 2003. Contribution of contact toxicity and wheat condition to mortality of stored-product insects exposed to spinosadt. Pest Manag Sci 59(5): 538-544. https://doi.org/10.1002/ ps. 660

25. Harein PK, Davis R. 1992. Control of stored-grain insects. Storage of Cereal Grains and Their Products. Edited by Sauer DB. Am. Assoc. Cereal Chem. St. Paul, Minnesota, USA.

26. Perez-Mendoza J. 1999. Survey of insecticide resistance in Mexican populations of maize weevil, Sitophilus zeamais Motschulsky (coleoptera: curculionidae). J Stored Prod Res 35(1): 107-115. https:// doi.org/10.1016/S0022-474X(98)00017-4

27. Patil NS,JadhavJP.2015. Significance of Penicillium ochrochloron chitinase as a biocontrol agent against pest Helicoverpa armigera. Chemosphere 128: 231-235. https://doi.org/10.1016/j.chemosphere.2015.01.038

28. Akhtar S, Mansoor U-H, Sagheer M, Javed N. 2015. Antifeedant effect of essential oils of five indigenous medicinal plants against stored grain insect pests. Pak J Zool 47(4): 1045-1050.

29. Chiam WY, Huang Y, Chen SX, Ho SH. 1999. Toxic and antifeedant effects of allyl disulfide on Tribolium castaneum (Coleoptera: Tenebrionidae) and Sitophilus zeamais (Coleoptera: Curculionidae). J Econ Entomol 92(1): 239-245. https://doi.org/10.1093/jee/92.1.239

30. Ebadollahi A, Zavieh EA, Nazifi A, Sendi JJ, Farjaminezhad M, et al. 2014. Chemical composition and bio-pesticidal values of essential oil isolated from the seed of Heracleum persicum Desf. elx Fischer (Apiaceae). Span J Agric Res 12(4): 1166-1174.

31. Huang Y, Lam SL, Ho SH. 2000. Bioactivities of essential oil from Elletaria cardamomum (L.) Maton to Sitophilus zeamais Motschulsky and Tribolium castaneum (Herbst). J Stored Prod Res 36(2): 107-117. https://doi.org/10.1016/S0022-474X(99)00040-5

32. Kiran S, Prakash B.2015. Toxicity and biochemical efficacy of chemically characterized Rosmarinus offcinalis essential oil against Sitophilus oryzae and Oryzaephilus surinamensis. Ind Crops Prod 74: 817-823. https://doi. org/10.1016/j.indcrop.2015.05.073

33. Nenaah GE. 2014. Toxic and antifeedant activities of prenylated flavonoids isolated from Tephrosia apollinea $\mathrm{L}$. against three major coleopteran pests of stored grains with reference to their structureactivity relationship. Nat Prod Res 28(24): 2245-2252. https://doi.org/1 $0.1080 / 14786419.2014 .932788$

34. Sahaf BZ, Moharramipour S, Meshkatalsadat MH. 2007. Chemical constituents and fumigant toxicity of essential oil from Carum copticum against two stored product beetles. Insect Sci 14: 213-218. https://doi. org/10.1111/j.1744-7917.2007.00146.x

35. Kharter KS, El-Shafiey SN. 2015. Insecticidal effect of essential oil from two aromatic plants against Tribolium castaneum (Herbst), (Coleptera: Tenebrionidae). Egyptian Journal of Biological Pest Control 25(1): 129134

36. Fell D, Ioneda T, Chiba S, Giannot O. 1982. Effect of disulfoton (disyston) on protein and carbohydrate content of the nervous system of Periplaneta americana L. Arquivos Do Institiuto Biological -O-SaoPaulo 49: 31-36.

37. Heller J, Moklowska A. 1930. U ber die zusammensetzug des raupenbluttes bei Deilephila euphobiae und deren Veranderungen der metamorphose. Biochem Zeitschr 219: 473-489.

38. Chaudahary KD, Bernard R, Lemonde A. 1964. Effects of starvation on the larval body composition and phosphorus metabolism in Tribolium confusum DuVal. Arch Int Physiol Biochim 72(1): 17-31. https://doi. org/10.3109/13813456409105249 